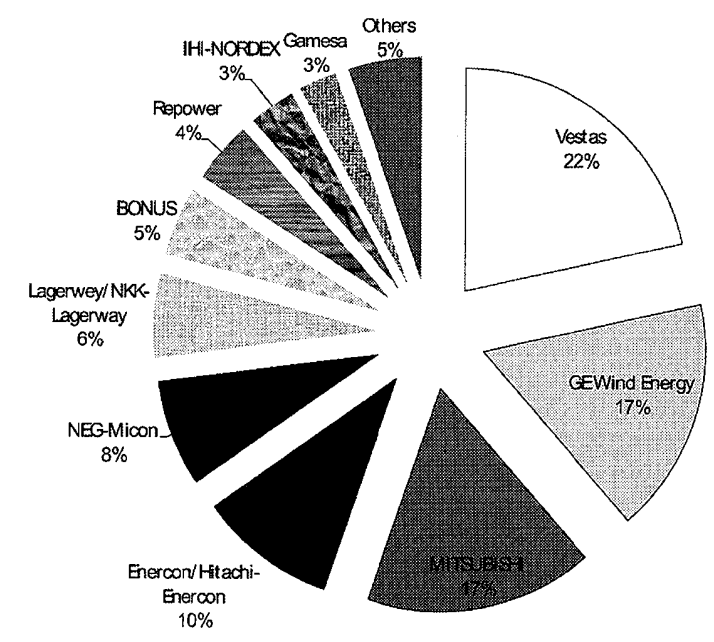

図 4 我が国の風車メーカーごとのシェア（設備容量計）

台風で倒壊・破損した経験を持つ我が国では, 耐久商品と しての風車が台風等の異常気象のもとでも安全性を維持する ことは重要であるが, 建築物とは異なる設計寿命を有する風 車に対して，同一の基準で良いのかという議論をはじめ，各 種の許認可申請が多くの省庁に分散していること, 系統連系 に関わる問題, など, 我が国では風力発電に対する制度面の 体制が欧米に比べ未熟である。結果として，こうした制度面 の遅れが，開発速度を遅らせる現状につながっている。

\section{(2) 今後の重要課題}

現在, 国際的な重要課題はやはり「地球温暖化」問題であ る。また, 京都議定書の目標年を 2 年後に迎えるなか, すで にポスト京都の目標設定に焦点が当てられている。

G8（2007年 6 月）ではEU, 日本，カナダは 2050 年までに 温室効果ガス排出の $50 \%$ を削減するべきであると主張した。 その後 $\mathrm{EU} 2020$ 年までに最低 $20 \%$ 削減を揭げるようになっ た。

風力発電は温暖化防止の有力な手段であり, 諸国で積極的 に推進されている。EWEA (欧州風力エネルギ協会) と GWEC (Global Wind Energy Council, 世界風力会議) は2020 年には 風力発電で電力の $12 \%$ を賄おう, という “Wind Force 12” を 提唱している。また米国エネルギー省は2030年までに風力で 電力の $20 \%$ を供給すべきであると提唱している。

残念ながら我が国では, 環境・エネルギー政策の中での風 力発電の位置づけは, 欧米諸国と比べると異常なほど非常に 低く, 基礎から応用に至る本格的な風力技術研究開発や長期 的な開発計画・目標（ロードマップ）すらない。

\section{文 献：References}

1) Wind Power Monthly, 2008 年 4 月号

\section{5 海 洋}

海洋エネルギーは, 近年世界的に見直され, 実用化推進に 向けて大きく動きだしている。特に地球規模でエネルギー問 題や環境問題が深刻化するなか, 欧米を中心に再生可能エネ ルギーのうちの一つの柱として注目されている。欧州では, 欧 州委員会のもと, 各国で多くの実用化に向けたプロジェクト が推進されている。特に, 波エネルギーが豊富な欧州では, EC における商業用に開発された波力エネルギーのコスト目標值 を0.04ユーロ/kWhとし推進している。一方米国では, 近年 エネルギー省や民間を中心としたEnergy Oceanという国際会 議が毎年開催されており，20社以上の海洋エネルギーの関連 企業が展示を行っている。また, 民間企業による潮流発電事 業が始まり, 最終的には，2008年に10MW，8,000世帯分の電 力供給を目指している。さらに, カナダでは, 4 つの州が海 洋エネルギーの開発を表明しており, 約70の企業や政府系機 関の組織からなるOREG という組織を設立し, 多くの民間企 業の出資により実証プロジェクトが計画されている。また, 英 国においては海洋エネルギーの技術開発と実証に関する世界 のリーダーとして近年台頭し，数多くの取り組みを実施して いる。特に，英国貿易産業省 (DTI) が積極的にリーダーシッ プを発揮している。2005年11月には今後の海洋エネルギー開

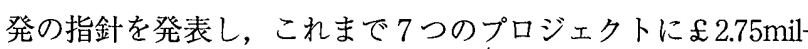
lion を補助し今後, £ 17.3million（約 40 億円）をかけて合計 16 のプロジェクトを支援していく計画を発表している。

一方，海洋エネルギーに関する世界的な組織としては，IEA の中に「海洋エネルギーシステムに係る実施協定」にもとづ くIEA-OES(Ocean Energy System)がある。IEA-OESは，2001 年にポルトガル，英国，デンマークの3 カ国で発足したが，現 在は，我が国（2002 年に加入）や米国（2005 年に加入）を含 む12力国と地域が参加し，近年急激に参加国が増加している。 IEA-OESは, 欧州や米国, カナダなど世界的に海洋エネルギー 利用の実用化が進むなか，国際的な推進役を担っている。 2007 年より海洋エネルギーの利用の本格的な推進を目指し, 分散型の海洋エネルギーを電力系統に統合するための諸問題 を国際的に解決するために，新たな Annex III (Integration of Ocean Energy Plants to Electrical Grids）が立ち上がった。

このように，海洋エネルギーの開発は，世界的にも基礎研 究の段階から, 実証研究及び実用化推進, 民間投資による開 発の段階に入っている。

このような状況の中，我が国においても本年「海洋基本法」 が施行された。これを契機として, 海洋立国として海洋エネ ルギー資源を含む海洋の利用・開発が積極的に行われること が期待され, 我が国に㧍いても海のポテンシャル, 海洋技術 のポテンシャルを見直す動きが各方面で盛んになってきてい る。 